\title{
Infliximab therapy together with tyrosine kinase inhibition targets leukemic stem cells in chronic myeloid leukemia
}

Oliver Herrmann ${ }^{1}$, Maja Kim Kuepper ${ }^{1}$, Marlena Bütow ${ }^{1}$, Ivan G. Costa², Iris Appelmann', Fabian Beier ${ }^{1}$, Tom Luedde ${ }^{3}$, Till Braunschweig ${ }^{4}$, Steffen Koschmieder ${ }^{1}$, Tim H. Brümmendorf ${ }^{1}$ and Mirle Schemionek ${ }^{1 *}$ (D)

\begin{abstract}
Background: Expression of Bcr-Abl in hematopoietic stem cells is sufficient to cause chronic myeloid leukemia (CML) and tyrosine kinase inhibitors (TKI) induce molecular remission in the majority of CML patients. However, the disease driving stem cell population is not fully targeted by TKI therapy, and leukemic stem cells (LSC) capable of re-inducing the disease can persist. Single-cell RNA-sequencing technology recently identified an enriched inflammatory gene signature with TNFa and TGF $\beta$ being activated in TKI persisting quiescent LSC. Here, we studied the effects of human TNFa antibody infliximab (IFX), which has been shown to induce anti-inflammatory effects in mice, combined with TKI treatment on LSC function.

Methods: We first performed GSEA-pathway analysis using our microarray data of murine LSK cells (lin ${ }^{-}$; Sca- $1^{+}$;

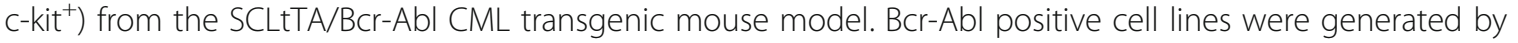
retroviral transduction. Clonogenic potential was assessed by CFU (colony forming unit). CML mice were treated with nilotinib or nilotinib plus infliximab, and serial transplantation experiments were performed.

Results: Likewise to human CML, TNFa signaling was specifically active in murine CML stem cells, and ectopic expression of Bcr-Abl in murine and human progenitor cell lines induced TNFa expression. In vitro exposure to human (IFX) or murine (MP6-XT22) TNFa antibody reduced clonogenic growth of CML cells. Interestingly, TNFa antibody treatment enhanced TKI-induced effects on immature cells in vitro. Additionally, in transplant and serial transplant experiments, using our transgenic CML mouse model, we could subsequently show that IFX therapy boosted TKI-induced effects and further reduced the proportion of malignant stem cells in vivo.

Conclusion: TNFa signaling is induced in CML stem cells, and anti-inflammatory therapy enhances TKI-induced decline of LSC, confirming that successful targeting of persisting CML stem cells can be enhanced by addressing their malignant microenvironment simultaneously.
\end{abstract}

Keywords: CML, Leukemic stem cells, Inflammation, Tyrosine kinase inhibitor, Infliximab, TNF, Therapy, Mouse model

\footnotetext{
* Correspondence: mschemionek@ukaachen.de

${ }^{1}$ Department of Hematology Oncology Hemostaseology and Stem Cell

Transplantation Faculty of Medicine, University Hospital RWTH Aachen,

Pauwelsstr 30, 52074 Aachen, Germany

Full list of author information is available at the end of the article
}

(c) The Author(s). 2019 Open Access This article is distributed under the terms of the Creative Commons Attribution 4.0 International License (http://creativecommons.org/licenses/by/4.0/), which permits unrestricted use, distribution, and reproduction in any medium, provided you give appropriate credit to the original author(s) and the source, provide a link to the Creative Commons license, and indicate if changes were made. The Creative Commons Public Domain Dedication waiver (http://creativecommons.org/publicdomain/zero/1.0/) applies to the data made available in this article, unless otherwise stated. 


\section{Background}

Chronic myeloid leukemia (CML) is a myeloproliferative neoplasm developing upon acquisition of the reciprocal translocation $\mathrm{t}(9 ; 22)$ within the hematopoietic stem cell (HSC) compartment. The mutation gives rise to the constitutively activated tyrosine kinase Bcr-Abl that contains multiple interaction sites, activating a variety of signaling pathways. Bcr-Abl positive leukemic cells show increased proliferation, differentiation, genomic instability and survival $[1,2]$. The implementation of tyrosine kinase inhibitors (TKI) induced very high response rates but while the majority of newly diagnosed CML-CP patients respond well to TKI treatment, about one-third develop primary or secondary resistance or intolerance to TKIs. Beyond that, others and we have previously demonstrated that even in patients responding well to TKI therapy the disease-driving CML stem cell population (leukemic stem cells, LSCs) persists [3-5]. This LSC persistence has been assigned to a lack of oncogene addiction within the malignant stem cell compartment. As a result, treatment-free remission can currently be achieved only in about $12 \%$ of patients upon first-line imatinib treatment [6].

Recent data have shown that therapy persistence in LSCs is at least in part mediated via the stem cell specific microenvironment, and an increasing number of reports suggest that the BM niche composition in CML differs from a normal niche. Soluble factors that are abnormally produced in CML include IL-1 $\alpha$, IL-1 $\beta$, IL-6, TNF $\alpha$, MIP-1 $\alpha$ MIP-1 $\beta$, G-CSF or CXCL12 [7-9]. Some of them, such as IL-1 and IL-6, have already been shown to support malignant stem cell function in CML [10-13].

Interestingly, many of these cytokines can be induced by $\mathrm{TNF} \alpha$, and TNF $\alpha$ is likewise increased in CML patients as well as in a transgenic SCLtTA/Bcr-Abl CML mouse model [8,9]. Although LSCs are difficult to separate from their normal counterparts due to a similar immunophenotype and biology, a recent report using single-cell RNA-sequencing technology achieved to discriminate $\mathrm{Bcr}-\mathrm{Abl}$ positive and negative stem cells via expression of the oncogene itself. Using this approach, the authors identified a malignant stem cell population reflecting a gene signature associated with either cycling or quiescence, with the latter population persisting in patients despite therapy. Signaling pathway analysis revealed activated TGF $\beta$ and TNF $\alpha$ signaling via NF-kB in these persisting LSCs [14].

Infliximab (IFX) is a chimeric antibody neutralizing TNF $\alpha$ in humans and is approved for multiple applications including ulcerative colitis, rheumatoid arthritis, Crohn's disease, or psoriatic arthritis. In a variety of preclinical mouse models, IFX application has been used as an anti-inflammatory therapy showing reduction of TNF $\alpha$ in the mice upon application [15-22]. Recently, it has been shown that reduction of TNF $\alpha$ in mice along with a decline of further pro-inflammatory cytokines is not mediated via a direct interaction of IFX and TNF $\alpha$ and the mechanism underlying the anti-inflammatory response in mice has thus to be clarified [23].

Similar to human CML, we here show that TNF $\alpha$ signaling is activated in murine CML stem cells and that TNF $\alpha$ targeting enhanced TKI-induced reduction of clonogenic activity. Aiming to test an antibody-based therapeutic approach, targeting inflammation along with TKI therapy in vivo, we subsequently applied our transgenic SCLtTA/Bcr-Abl CML mouse model [24]. In this model, malignant stem cells were further reduced by IFX therapy combined with TKI as compared to TKI standard treatment alone.

\section{Methods}

Cell culture

32Dcl3 (here after named as 32D) and BA/F3 cells (ACC-411, ACC-300, DSMZ, 2018-01) were cultured as described previously $[25,26]$. TF-1 cells (ACC-334, DSMZ, 2018-01) were cultured using RPMI 1640/ $10 \%$ FCS/GM-CSF $(5 \mathrm{ng} / \mathrm{ml})$. All cell lines were routinely tested for mycoplasma using PCR. Authentication of cell lines was performed using qRT-PCR for murine or human housekeeping gene as well as cell surface expression of characteristic receptor expression pattern (CD34, CD11b, Gr-1) using FACS analysis. Primary murine cells were cultured in serum-free BIT9500 cell culture medium (Stem Cell Technologies, Vancouver, BC, Canada) supplemented with mIL-3 (10 ng/ml), mIL-6 (5 $\mathrm{ng} / \mathrm{ml})$ and $\mathrm{mSCF}(50 \mathrm{ng} / \mathrm{ml})$. All cytokines were purchased form ImmunoTools, (Friesoythe, Germany). Further, lineage negative transgenic SCLtTA/Bcr-Abl $\mathrm{BM}$ cells were retrovirally infected using MSCV-ERHoxb8-Neo plasmid as described previously [27]. ERHoxB8 derived immortalized progenitor cells were cultured in IMDM containing 10\% FBS, 5\% SCFsupernatant and 1\% Pen-Strep and selected with G418 $(1 \mathrm{mg} / \mathrm{ml})$ for 1 week. FACS analysis for Gr-1, CD11b, B220, CD3 and Ter119 (BioLegend, Fell, Germany) were performed demonstrated the absence of mature cell surface markers.

\section{Isolation of primary cells}

Mice were sacrificed by cervical dislocation in isoflurane anesthesia. Murine Bone marrow (BM) cells were isolated from tibia and femora of SCLtTA/Bcr-Abl mice by flushing the marrow with PBS supplemented with $2 \%$ fetal calf serum (FCS). Cells were subjected to red blood cell lysis using ammonium-chloride-potassium buffer (0.15 $\mathrm{M} \mathrm{NH}_{4} \mathrm{Cl}, 1 \mathrm{mM} \mathrm{KHCO} 3,0.1 \mathrm{mM} \mathrm{Na}$-EDTA, pH 7.3). Lineage negative cell isolation was performed by magnetic-activated cell sorting (MACS) using the mouse 
lineage depletion kit (Milteny Biotec, Bergisch Gladbach, Germany).

\section{Retroviral transduction}

Retroviral transduction was performed following previously described protocols $[28,29]$. Briefly, Plate-E packaging cells were transfected using MSCV-BcrAblIRES-RFP and MSCV-IRES-RFP empty vector. Viral supernatant was collected after $24 \mathrm{~h}$ and subsequently centrifuged onto RetroNectin-coated (Takara Bio Europe/Clontech, France) six-well plates. $1 \times 10^{6} 32 \mathrm{D}$ and BA/F3 cells were added and cultured for 2 days before FACS sorting for vector encoded RFP expression.

\section{Real-time quantitative reverse transcriptase-PCR (qRT- PCR)}

Total RNA was isolated using Trizol reagent (Thermo Fischer Scientific, Waltham, MA, USA) as described previously [30]. mRNA expression of human and murine TNF $\alpha$ was measured with a 7500 Fast Real-Time PCR cycler (Applied Biosystems, Waltham, MA, USA) using SYBR-Green reagent (Thermo Fischer Scientific) with the following primer pairs: TNF- $\alpha$ forward 5'-GTAG CCCACGTCGTAGCAAA-3'; TNF- $\alpha$ reverse 5' $5^{\prime}$ ACAA GGTACAACCCATCGGC-3'; INF $\gamma$ forward 5'-ACGG CACAGTCATTGAAAGC-3'; INF $\gamma$ reverse 5'-TCAC CATCCTTTTGCCAGTTC-3'; GAPDH forward 5'TTGTGCAGTGCCAGCCTC-3' and GAPDH reverse 5' -CCAATACGGCCAATCCG-3'. Bcr-Abl expression was assessed using hydrolyzing TaqMan probes and primers: Bcr-Abl forward 5'-CGTCAACTCAGCCACT GG-3'; Bcr-Abl reverse 5'-GGCTTCACTCAGACCCT GA-3'; Bcr-Abl probe 5'-FAM-AGCGGCCAGTATCATCTGACTTTGAGC-TAMRA-3'; A20 forward 5'GAACAGCGATCAGGCCAGG-3'; A20 reverse 5'-GG ACAGTTGGGTGTCTCACATT-3'. GAPDH forward and GAPDH reverse primer were used as mentioned above and combined with GAPDH probe $5^{\prime}$-FAM-TC CCGTAGACAAAATGGTGAAGGTCGGT-TAMRA-3'.

\section{Apoptosis and proliferation assays}

For apoptosis and proliferation analyses $5 \times 10^{\wedge} 5$ cells per $\mathrm{ml}$ were treated with or without $0.05 \mathrm{ng} / \mathrm{ml} \mathrm{TNF}$, $100 \mathrm{nM}$ Nilotinib, $2.5 \mu \mathrm{g} / \mathrm{ml}$ MP6-XT22 or DMSO as control. For proliferation analysis, the cells were stained using Trypan Blue and counted using a hemocytometer after 24 and $48 \mathrm{~h}$ of treatment. Early and late apoptotic cells were stained using an APC Annexin V Apoptosis Detection Kit with 7-AAD (BioLegend) upon $48 \mathrm{~h}$ of treatment. Proportional distribution was assessed via Flow cytometry analysis using a Gallios flow cytometer (Beckman Coulter, Krefeld, Germany) and Kaluza (Version 1.3) analysis software.

\section{Preparation of cell lysates, SDS-PAGE and immunoblotting}

Cell lysates and western blot (WB) analysis was performed as previously described [29] using following anti-

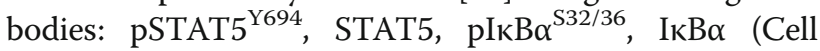
Signaling, Danvers, MA, USA), and GAPDH (Santa Cruz, Heidelberg, Germany).

\section{Mice and genotyping}

CD45.1 $1^{+}$SCLtTA (BDF-FVB/N background backcrossed to $\mathrm{FVB} / \mathrm{N}$ for $4-6$ generations) and $\mathrm{Bcr}-\mathrm{Abl}(\mathrm{FVB} / \mathrm{N}$ background) mice were genotyped as described previously [24]. Recipient FVB/N CD45.2 ${ }^{+}$mice were bred in-house.

\section{Colony formation assay}

Lineage depleted SCLtTA/Bcr-Abl BM cells were treated for $72 \mathrm{~h}$ with TKI $100 \mathrm{nM}$ nilotinib (LC Laboratories, Woburn, MA, USA), $500 \mu \mathrm{g} / \mathrm{ml}$ infliximab (Remicade, Jansen Biologics) or in combination. Nilotinib was added freshly every day. Treated cells were subjected to methylcellulose (MethoCult GF M3434; Stem Cell Technologies). Additionally, murine anti-TNF $\alpha$ antibody $(2 \mu \mathrm{g} / \mathrm{ml}$, clone MP6-XT22, eBioscience, San Diego, CA, USA) was used. Colony numbers were determined on day 7 using a light microscope.

\section{Bone marrow transplantation and treatment of mice}

$\mathrm{BM}$ cells were isolated from SCLtTA/Bcr-Abl and wildtype (wt) mice in an $\mathrm{FVB} / \mathrm{N}$ background. $\mathrm{BM}$ cells from three SCLtTA/Bcr-Abl mice were pooled. Transplantation was performed using $1.5 \times 10^{6}$ wt or Bcr-Abl BM cells expressing $\mathrm{CD} 45.1$ by tail vain injection. $\mathrm{FVB} / \mathrm{N} 45.2^{+}$wt recipients were irradiated using $10 \mathrm{~Gy}$. Mice were treated with cotrimoxazole (Ratiopharm, Ulm, Germany) for 2 weeks after transplantation. Cells were allowed to engraft and expand for 14 days. Bcr-Abl transplanted mice were treated with TKI nilotinib $(50 \mathrm{mg} / \mathrm{kg}$, daily) by oral gavage alone or combined therapy with the chimeric antibody infliximab $(10 \mathrm{mg} / \mathrm{kg}$, weekly i.v., tail vein). Control mice were treated with vehicle alone or together with human IgG control $(10 \mathrm{mg} / \mathrm{kg}$, weekly i.v., Sigma Aldrich, St. Louis, MO, USA). All mice were sacrificed after $2-5$ weeks of treatment.

\section{Flow cytometry analysis}

$\mathrm{BM}$ cells were isolated from tibie and femora by flushing with PBS/2\% FBS. Peripheral blood (PB) was drawn from the orbital plexus. Spleen cells were separated by a $100 \mu \mathrm{M}$ cell strainer (Greiner Bio-one, Frickenhausen, Germany). Red blood cell lysis was applied using ammonium-chloride-potassium buffer. The following antibodies were used for phenotyping by FACS: CD45.1, CD45.2, Gr-1, CD11b, c-kit, B220 (BioLegend). The LSK 
cell compartment was analyzed using tricolor- or PECy5 labeled CD4, CD8a, B220 (life technologies, Carlsbad, CA, USA), Gr-1, Ter119 and CD11b (BioLegend) to label $\operatorname{lin}^{+}$cells. Furthermore, lineage-negative cells were analyzed for $\mathrm{LSK}^{+}$cells using c-kit APC-Cy7 (BioLegend) and Sca-1 (biotin labeled first antibody and streptavidin PE-Cy7 secondary antibody, BD Bioscience, Franklin Lakes, NJ, USA). CD45.1-FITC, CD45.2-PE (BioLegend) was used to discriminate between donor and recipient cells. FACS measurements were performed using a Gallios Flow Cytometer (Beckman Coulter, Krefeld, Germany). FACS data were analyzed with Kaluza (Version 1.3) or FlowJo Software (Version 10).

\section{Statistical analysis}

Two-sided Student's t-test, 1-way or 2-way Anova using Bonferroni post-test (GraphPad Prism software) were used as applicable for statistical analysis. Error bars are given as standard error of the mean (s.e.m). Log-rank test was performed for Kaplan-Meier survival analysis. $\left.p<0.05{ }^{(*)}\right), p<0.01^{(* *)}, p<0.0011^{(* *)}$ ) were considered as statistical significant.

\section{Results}

TNFa gene expression signature in leukemic stem and progenitor cells

Using an inducible transgenic CML mouse model (SCLtTA/Bcr-Abl) as well as primary patient material, we previously identified leukemic stem cells (LSC) that persist despite complete Bcr-Abl inhibition [4]. Applying the same mouse model, we here performed Gene Set Enrichment Analysis (GSEA) [31] of our previously published microarray data from CML vs normal LSK $\left(\right.$ lin $^{-}$; c-kit ${ }^{+}$; Sca- $\left.1^{+}\right)$cells [24] that are highly enriched for stem cells. These data identified TNF $\alpha$ signaling as the most significant upregulated pathway in CML LSK cells vs controls (Additional file 1). In particular, expression of the NF- $\mathrm{kB}$ family members $\mathrm{IkB} \alpha, \mathrm{BCL}-3$ and Relb were significantly increased by 1.8 -fold using two different $\mathrm{IkB} \alpha$ probes as well as 2.5-fold and 2.9-fold respectively (Fig. 1a) reflecting NF- $\mathrm{kB}$ activity. Using qRT-PCR, we found that TNF $\alpha$ gene expression was likewise significantly increased in LSK cells from CML mice as compared to controls (2.01-fold, Fig. 1b). Aiming to analyze if TNF $\alpha$ upregulation was specific for the stem and progenitor cell compartment or not, we next tested whole BM cells from control and SCLtTA/ Bcr-Abl CML mice in that we induced the disease for 6 days by tetracycline withdrawal which lead to the activation of the oncogenic Bcr-Abl kinase. Analysis of TNF $\alpha$ expression in total BM cells revealed similar levels in control vs leukemic animals (Fig. 1c) showing that TNF $\alpha$ upregulation is specific for the stem and progenitor compartment in the CML mouse model. Next, we analyzed TNFa gene expression in the murine myeloid progenitor cell line 32D and the murine lymphoid progenitor cell line BA/F3 upon Bcr-Abl expression. Both progenitor cell types depend on IL-3 signaling and BcrAbl expression induces cytokine-independent growth. TNF $\alpha$ levels increased upon Bcr-Abl expression by 3.02fold in 32D cells and 12.06-fold in BA/F3 cells (Fig. 1d). In order to test TNF $\alpha$ expression also in human Bcr-Abl positive vs $\mathrm{Bcr}-\mathrm{Abl}$ negative progenitor cells, we virally infected the human erythroblastic $\mathrm{CD} 34^{+}$cell line TF-1 to express BCR-ABL. Again, TNF $\alpha$ expression was highly increased (11.76-fold) in Bcr-Abl positive cells (Fig. 1e).

In order to study if TNF $\alpha$ induced signaling is persisting despite Bcr-Abl inhibition in our model we analyzed phosphorylation of IKB $\alpha$. Therefore, we first conditionally immortalize early hematopoietic progenitor cell derived from the transgenic SCLtTA/Bcr-Abl model, using an estrogen-regulated HoxB8 variant [27]. IkB $\alpha$ blocks TNF $\alpha$-induced NF- $\mathrm{KB}$ activation by NF- $\mathrm{KB}$ binding that prevents its nuclear translocation. Phosphorylation of IKB $\alpha$ induces ubiquitination and thereby degradation of the NF- $\mathrm{KB}$ regulating kinase and this allows for NF- $\mathrm{KB}$ transcription factor activity. As expected, the presence of the TNFa neutralizing antibody MP6-XT22 abolished IKB $\alpha$ phosphorylation (Fig. 1f). However, nilotinib treatment alone failed to reduce $\mathrm{pIKB} \alpha$ and this could be largely overcome by combining MP6-XT22 with nilotinib. TKI persisting TNF $\alpha$ induced NF-кB activation was also shown by expression of A20, as a specific TNFo target gene. Nilotinib treatment did not reduce but rather increased the level of A20 gene expression (Fig. 1g). We proceeded to test if TNF $\alpha$ secretion by the malignant clone is Bcr-Abl dependent. Inhibition of Bcr-Abl using imatinib significantly reduced TNF $\alpha$ expression in 32D Bcr-Abl cells (Fig. 1h) suggesting that in this model TNF $\alpha$ levels depend on the malignant kinase activity. Next, we studied TNFo expression in LSK cells from SCLtTA/Bcr$\mathrm{Abl}$ mice, that were first induced to express Bcr-Abl for 25 days and then reverted to not express Bcr-Abl for 48 days [4]. Expression of TNF $\alpha$ in these previously malignant LSK cells was reverted to normal level (Fig. 1i).

\section{Pharmacological inhibition of Bcr-Abl and TNFa impairs leukemic progenitor cell growth}

As the inflammatory CML microenvironment has previously been shown to support stem cell persistence, we next aimed to evaluate the effect of infliximab (IFX) therapy combined with TKI on the clonogenic potential of CML cells. We first isolated linage negative (lin $\left.{ }^{-}\right) \mathrm{BM}$ cells from transgenic SCLtTA/Bcr-Abl mice using magnetic activated cell sorting (MACS) and induced these cells by removal of tetracycline in vitro to express BcrAbl. Treatment was performed for $72 \mathrm{~h}$ followed by cell seeding into a colony formation (colony forming unit, 


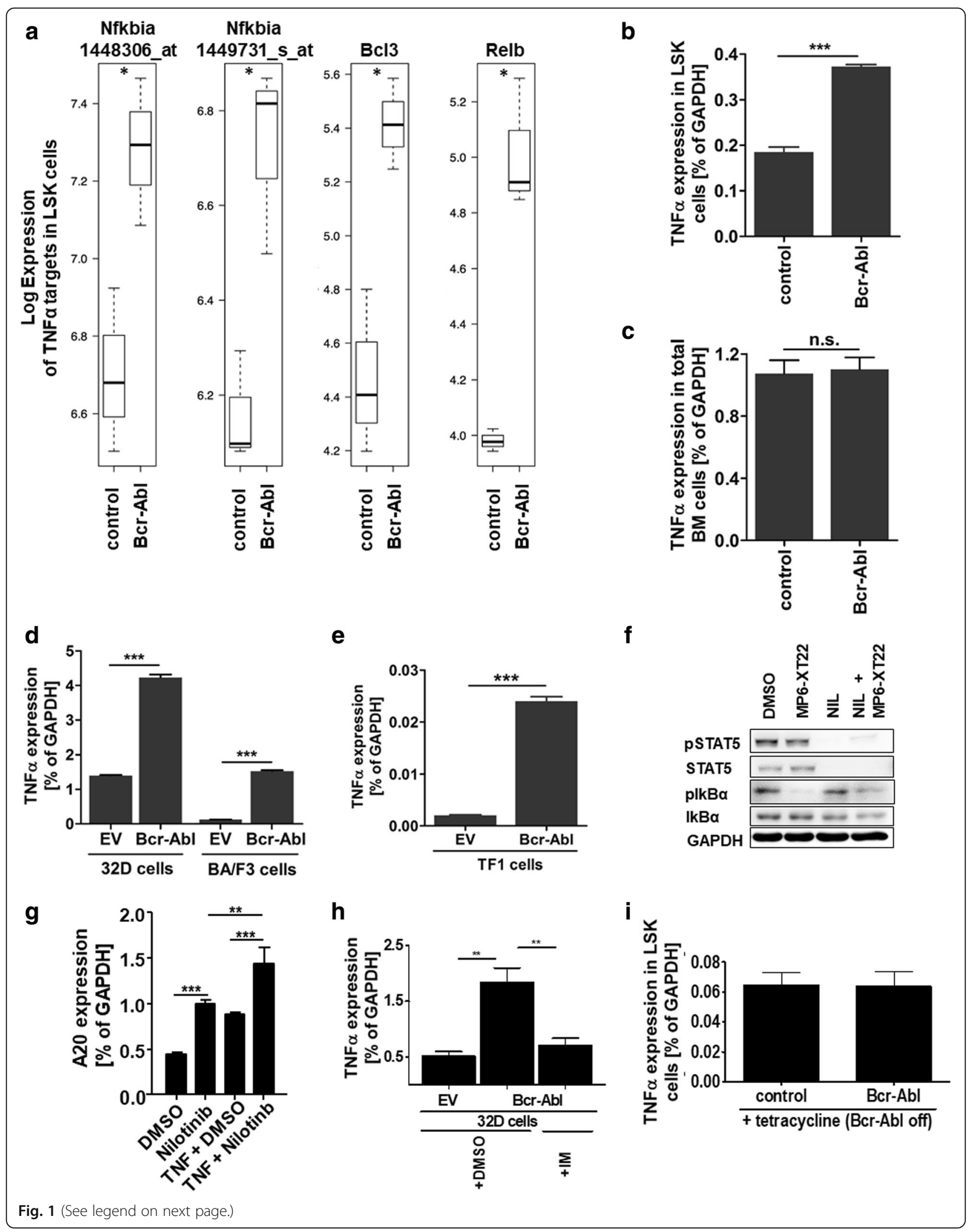


(See figure on previous page.)

Fig. 1 TNFa gene expression signature in leukemic stem and progenitor cells. a Gene Set Enrichment Analysis (GSEA) pathway analysis was performed from previously published microarray data (GSE\# 18446) that were obtained from SCLtTA/Bcr-Abl and control LSK (lin ${ }^{-}$; Sca-1 ${ }^{+}$; c-kit ${ }^{+}$) cells $(n=3 / 3)$. b Expression of TNFa was evaluated in a further set of murine SCLtTA/Bcr-Abl and control LSK cells by qRT-PCR $(n=3 / 3)$. $\mathbf{c}$ qRTPCR analysis of TNFa in total BM cells from murine SCLtTA/BCr-Abl and control mice $(n=3 / 3)$. d TNFa expression was assessed in 32D:EV, 32D:BCrAbl, BA/F3:EV and BA/F3:Bcr-Abl cells. e Human erythroleukemic cell line TF-1 was transduced with EV and Bcr-Abl and subsequently analyzed for TNFa expression by qRT-PCR. $\mathbf{f}$ HoxB8 immortalized progenitor BM cells from SCLtTA/Bcr-Abl mice were treated with MP6-XT22 (2 $\mu \mathrm{gg} / \mathrm{ml}), 100 \mathrm{nM}$ nilotinib or the combination of both agents in the presence of $0.05 \mathrm{ng} / \mathrm{ml}$ TNFa. Protein expression was analyzed using western blot. $\mathbf{g}$ Expression of the NF-KB target gene A20 was analyzed in HoxB8 immortalized progenitor BM cells from SCLtTA/Bcr-Abl mice upon Bcr-Abl inhibition using nilotinib $(100 \mathrm{nM})$ in the absence and presence of $0.05 \mathrm{ng} / \mathrm{ml}$ TNFa. $\mathbf{h}$ TNFa expression was analyzed in 32D:Bcr-Abl cells upon imatinib $(I M, 5 \mu M)$ treatment and $\mathbf{i}$ in LSK cells from SCLtTA/Bcr-Abl mice that had been induced to express Bcr-Abl for 25 days and were then reverted to not express the oncogene for 48 days. (n.s. $=$ not significant, ${ }^{* * *} p<0.001$ )

CFU) assay. Administration of IFX alone already significantly reduced the CFU capacity by $1.6-$ fold (Fig. 2a). As expected, nilotinib further reduced the CFU capacity by 4.4-fold as compared to control. Interestingly, combinational treatment showed superior effects and diminished CFU capacity by 6.5 -fold compared to untreated control. To evaluate self-renewal potential of these cells in vitro, we performed serial plating using $5 \times 10^{3}$ cells per $\mathrm{ml}$ without further treatment. Cells that had previously been treated with IFX showed a 1.9-fold decrease in re-plating efficiency and this was similar to nilotinib treated cells showing a 2.1-fold reduction in CFU numbers (Fig. 2b). Combinational treatment was most efficient and reduced clonogenic cells by 3.4-fold. Although IFX has been previously applied to reduce TNF $\alpha$ levels in a variety of mouse models [15-22] a recent report showed that IFX-induced anti-inflammatory response including TNF $\alpha$ reduction in mice is not mediated via direct TNF $\alpha$ binding [23] unlike to human. To further validate our results, we additionally used a murine specific TNF $\alpha$ neutralizing antibody (MP6-XT22, $2 \mu \mathrm{g} / \mathrm{ml}$ ) and treated lin $^{-}$SCLtTA/Bcr-Abl BM cells accordingly but added murine TNF $\alpha(0.05 \mathrm{ng} / \mathrm{ml})$ in addition to mimic the increased TNF $\alpha$ levels in patients. CFU capacity was increased (1.5-fold) upon TNF $\alpha$ addition alone in the DMSO control group (Fig. 2c) showing that TNF $\alpha$ indeed supports malignant stem and progenitor cell growth. Moreover, nilotinib treatment was less effective in the presence of added TNF $\alpha$ and reduced CFU potential by only 1.3 -fold vs 1.8 -fold in the absence of the cytokine showing that TNFo supports the clonogenic potential and reduces the sensitivity to TKI therapy in these cells (Fig. 2c). The effect of the murinized TNF $\alpha$ antibody was less notable as compared to IFX in the first plaiting and could only induce limited but significant reduction of the CFU potential upon replaiting (Fig. 2d). However, cells that had been subjected to the combinational treatment were again significantly reduced in CFU capacity as compared to nilotinib treatment alone (Fig. 2d). Similar results were obtained when we treated Hoxb8 immortalized progenitor cells derived from transgenic SCLtTA/Bcr-Abl mice (Fig. 2e).
To study the mechanism resulting in impaired CML cell biology upon TNF $\alpha$ inhibition we applied 32D Bcr-Abl cells that were subjected to TNF $\alpha$ antibody treatment, nilotinib therapy or the combination, upon adding or not adding physiological TNF $\alpha$ concentration. As expected, apoptosis was significantly induced upon nilotinib treatment but not further enhanced upon additional TNF $\alpha$ targeting (Fig. 2f). TNF $\alpha$ targeting alone was not sufficient to induce apoptosis in these CML cells. Using the same model, we subsequently analyzed the effect on proliferation and here we could observe a significant reduction upon TNF $\alpha$ targeting alone. This was evident in CML cells independent of TNF $\alpha$ addition, likely because of TNF $\alpha$ expression per se in these cells (Fig. 1d). Nilotinib treatment by itself largely abolished proliferation in this model and thus there was no additional effect observable (Fig. 2g).

\section{Anti-inflammatory therapy together with TKI reduces leukemic stem cells in vivo}

To evaluate the effect of combined anti-inflammatory and TKI treatment on CML stem cells in vivo, we next tested the effect of nilotinib together with infliximab treatment in CML mice. To allow for discrimination of donor vs recipient cells we transplanted $1.5 \times 10^{6}$ CD45.1 $1^{+}$SCLtTA/Bcr-Abl BM cells into congenic FVB/ $\mathrm{N} \mathrm{CD} 45.2^{+}$recipients (Fig. 3a). Donor mice were induced to express Bcr-Abl by tetracycline withdrawal from the drinking water provoking splenomegaly in BcrAbl positive mice (data not shown). Total BM cells from Bcr-Abl positive mice were isolated and transplanted into 10 Gy irradiated recipients. Two weeks after transplantation peripheral blood (PB) analysis showed similar engraftment of transplanted cells in both recipient groups (Fig. 3b) and revealed a trend of increased (1.6fold) donor-derived CD $45.1^{+}$; Gr- $1^{+}$; CD $11 \mathrm{~b}^{+}$neutrophils in recipients of Bcr-Abl positive BM cells as expected (Fig. 3c). Subsequently, Bcr-Abl positive control mice were treated with vehicle or vehicle combined with human IgG $(10 \mathrm{mg} / \mathrm{kg}$ weekly) to control for the TKI solvent as well as the chimeric antibody IFX ( $n=6$ per group). Further, $2 \mathrm{Bcr}-\mathrm{Abl}$ positive cohorts were treated 

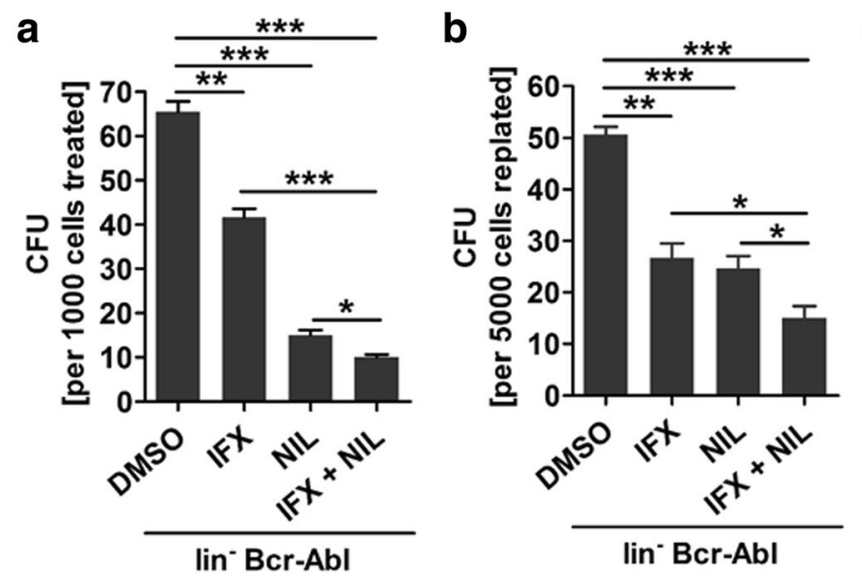

d

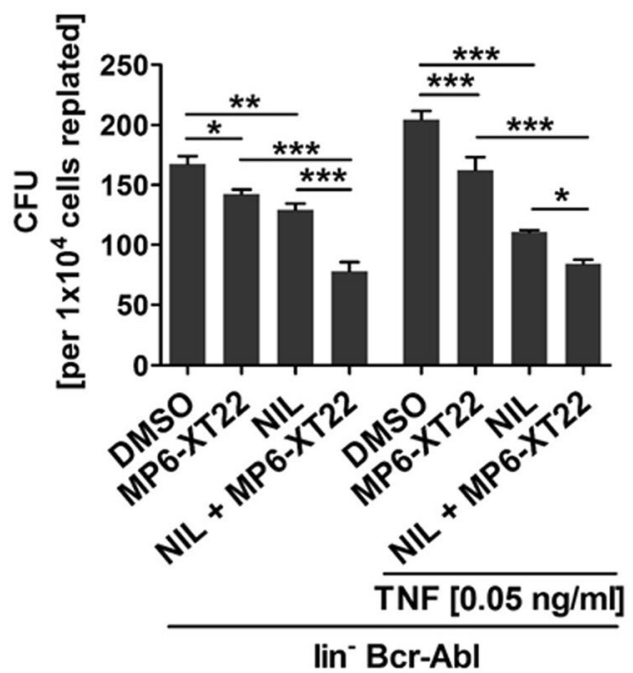

f

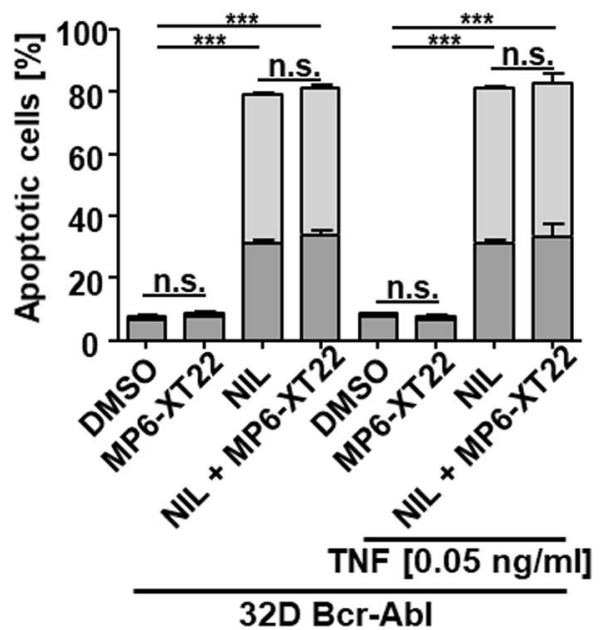

AnnexinVI 7AAD

AnnexinV
C
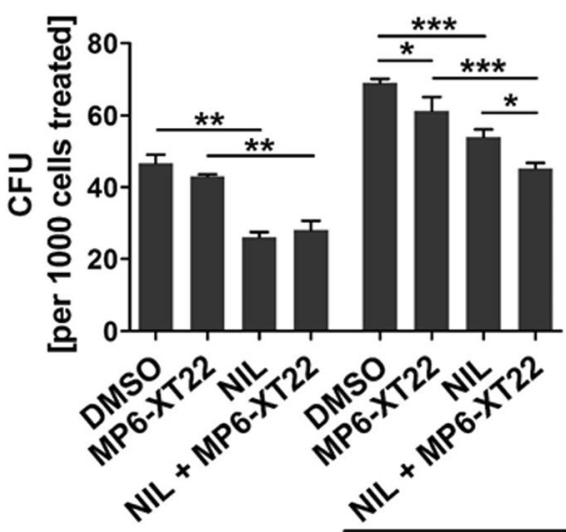

TNF $[0.05 \mathrm{ng} / \mathrm{ml}]$

lin $^{-} \mathrm{Bcr}-\mathrm{Abl}$

e

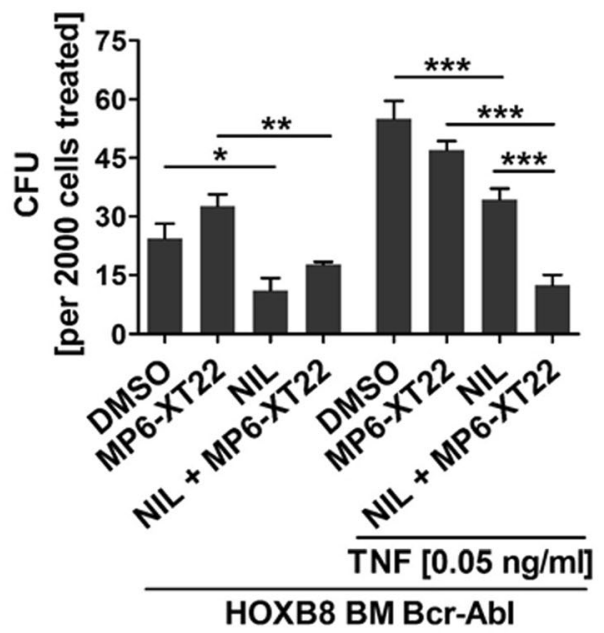

g

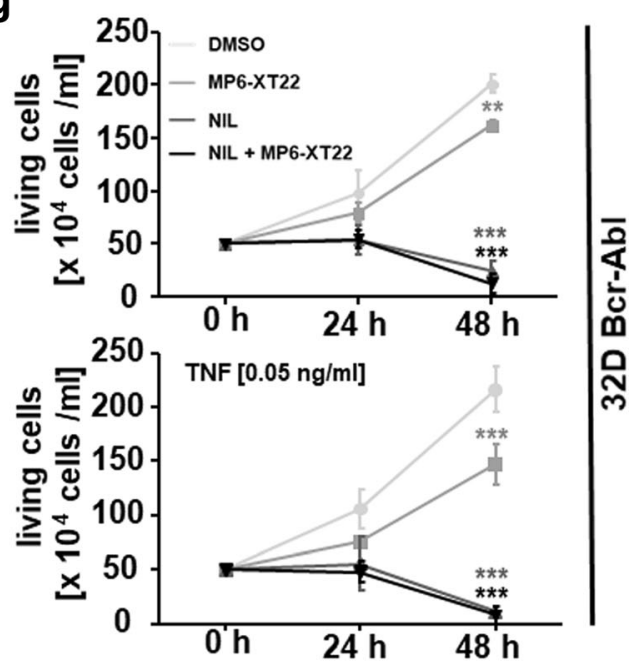




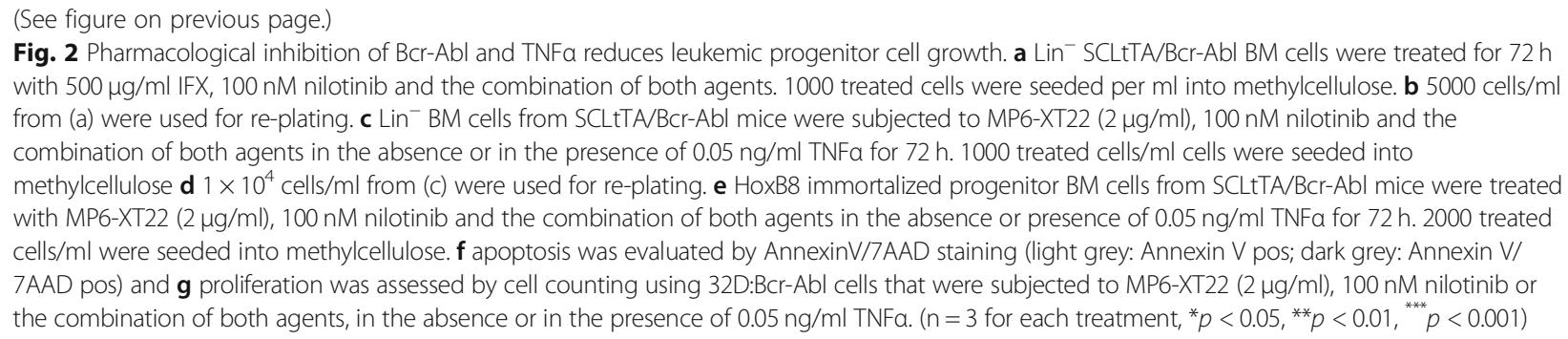

either with nilotinib $(50 \mathrm{mg} / \mathrm{kg}$ daily) or the combination of nilotinib and IFX ( $\mathrm{n}=6$ each group). Recipients of Bcr-Abl negative wt cells were implemented to control for disease development and were treated with vehicle. The therapy was continued for 18 days whereas several mice died during that period ( $2 \mathrm{Bcr}-\mathrm{Abl}$ mice treated with vehicle, $3 \mathrm{Bcr}-\mathrm{Abl}$ mice treated with vehicle and IgG as well as 2 Bcr-Abl mice treated with nilotinib and IFX). Neither of the 2 mice treated with nilotinib and IFX showed a splenomegaly at that stage whereas most of the vehicle or vehicle and IgG mice did (Table 1). Remaining mice were analyzed 18 days after therapy start and spleen weight was determined in all recipients (Fig. 3d). Mice that had been transplanted with Bcr-Abl positive BM cells and were treated with control agents developed splenomegaly as compared to wt. Nilotinib alone significantly reduced spleen weight by 2.20 -fold and a trend in reduction was likewise observed in mice that received IFX and nilotinib (1.52-fold) compared to vehicle and IgG control. Analysis of spleen cells confirmed Bcr-Abl mRNA expression in vehicle, vehicle and IgG, nilotinib and nilotinib and IFX treated animals (Fig. 3e). While nilotinib treatment could only induce a mild reduction in Bcr-Abl expression levels upon 18 days of treatment, the combination of nilotinib and IFX further reduced Bcr-Abl mRNA levels. Next we analyzed lin $^{-}$BM cells. Transplantation of Bcr-Abl positive BM increased lin $^{-}$cells in animals treated with control substances as expected (Fig. 3f) and TKI as well as combined treatment significantly reduced this cell fraction by 9.06 -fold and 8.22 -fold respectively. As nilotinib alone was extremely effective in reducing $\operatorname{lin}^{-} \mathrm{BM}$ cells, we could not observe an additional effect by adding IFX therapy at the progenitor cell level. We then analyzed $\mathrm{BM} \mathrm{LSK}^{+}$cells $\left(\mathrm{lin}^{-} ; \mathrm{c}-\mathrm{kit}^{+}\right.$; Sca- ${ }^{+}$) in these mice. Upon transplantation of wt BM we identified $6 \%( \pm 0.8)$ donor derived non leukemic CD45.1 $1^{+}$cells within the LSK compartment defining the baseline for non-leukemic LSK engraftment and expansion in this setting (Fig. 3g). Bcr-Abl positive mice, treated with vehicle or vehicle and IgG showed a significant increase in leukemic donor-derived CD45.1 ${ }^{+}$LSK cells (vehicle 41\% $( \pm 6.9)$; vehicle + IgG 32\% $( \pm 12.8)$ that did not differ significantly between both control groups. As expected nilotinib treatment significantly decreased leukemic LSK cells by 2.03-fold compared to control treated mice. Interestingly, we observed a 4.38 -fold reduction in leukemic LSK cells upon combined nilotinib and IFX treatment showing that the combination is capable of further diminishing TKI induced reduction of leukemic LSK cells by 2.81 -fold (Fig. 3g). Taken together, these data show that combined treatment significantly enhances decline of malignant stem cells and reduces the level of these cells down to $7 \%( \pm 3.9)$ that is marginally above wt baseline of $6 \%$.

\section{Serial transplantation reveals impaired malignant stem cell function in mice receiving combination therapy}

Aiming to test the LSC quality after treatment, we next performed serial transplantation experiments. $3 \times 10^{6}$ leukemic CD45.1 ${ }^{+} \mathrm{BM}$ derived cells from vehicle, vehicle + IgG, nilotinib, and nilotinib + IFX treated animals as well as wt controls were re-transplanted into irradiated congenic $\mathrm{FVB} / \mathrm{N}$ recipients $\left(\mathrm{CD} 45.2^{+}\right)$. We applied no further treatment in these secondary recipients and monitored the survival as well as the capacity of transplanted cells to induce early malignant cell expansion. Survival was significantly impaired in vehicle and vehicle + IgG re-transplanted mice as compared to nilotinib and nilotinib + IFX treated cell recipients (Additional file 2). No difference was observed in secondary recipients receiving either nilotinib or nilotinib + IFX treated cells presumably due to transplantation of high cell numbers that impair resolution of this endpoint. However, PB analysis showed clear differences in initial malignant cell expansion. Evaluation 4 weeks after re-transplantation revealed a significant engraftment of $\mathrm{CD} 45.1^{+}$donor derived cells in Bcr-Abl positive vehicle and vehicle + IgG re-transplanted animals (Fig. 4a). As expected a significant reduction of $\mathrm{CD} 45.1^{+}$donor derived cells was detected in nilotinib (3.36-fold) and nilotinib + IFX (3.89-fold) re-transplanted mice compared to vehicle and vehicle + IgG controls confirming that both treatments affected malignant stem and progenitor cells (Fig. 4a). Interestingly 6 weeks after re-transplantation, analysis of PB showed that leukemic CD $45.1^{+}$cells of nilotinib re-transplanted animals recovered and increased while this was not the case in cell recipients of 


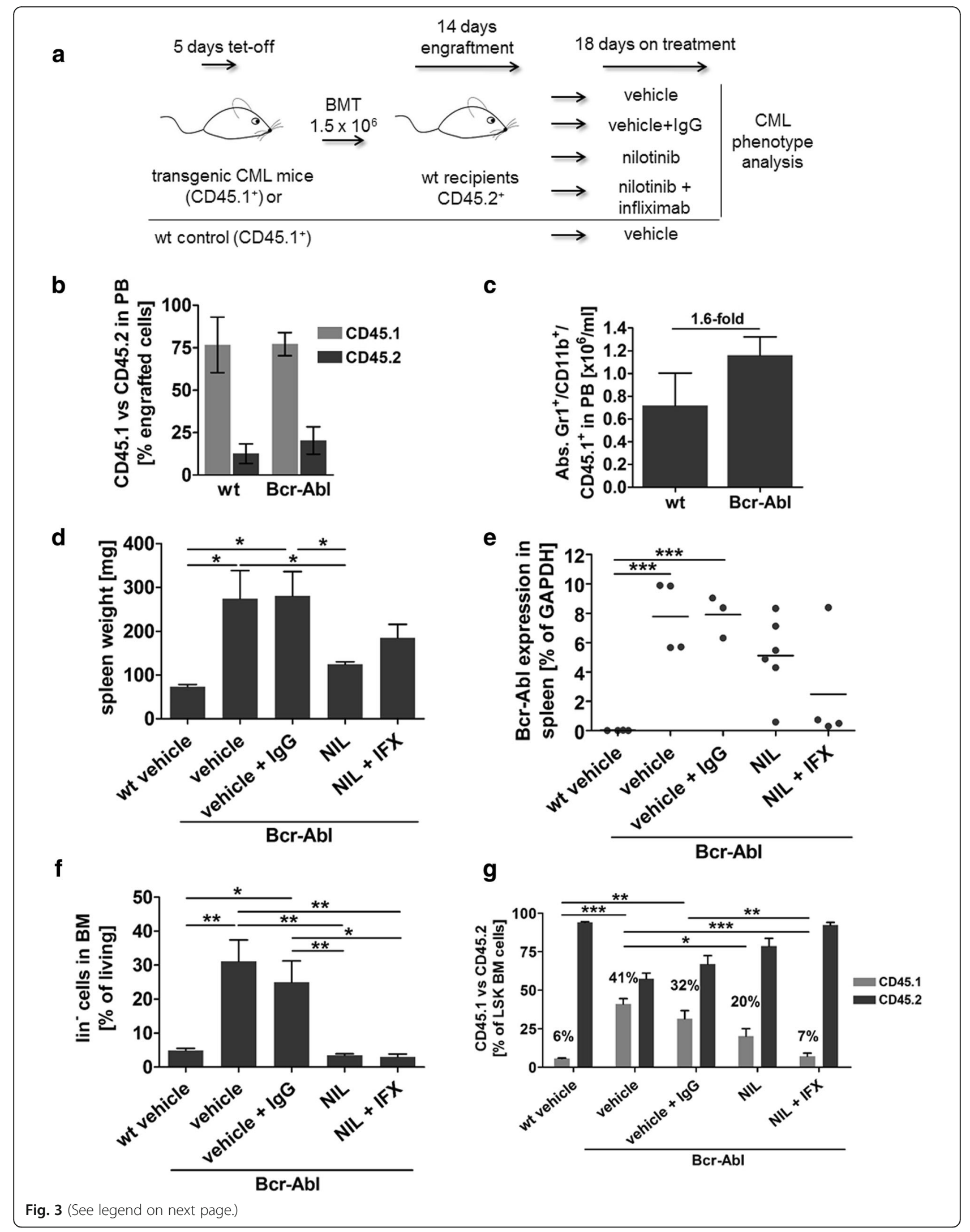


(See figure on previous page.)

Fig. 3 Anti-inflammatory therapy and Bcr-Abl inhibition reduces leukemic stem cells in vivo. a Experimental design for the treatment of Bcr-Abl and wt (CD45.1) BM transplanted recipient FVB/N mice (CD45.2). $\mathbf{b}$ Engraftment of CD45.1 $1^{+}$donor cells in the peripheral blood of Bcr-Abl and wt transplanted mice was evaluated by FACS $14 \mathrm{~d}$ after BMT $(n=3 / 3)$. c Absolute Gr- $1^{+} / \mathrm{CD} 11 \mathrm{~b}^{+} / \mathrm{CD} 45.1^{+}$cell number of wt and Bcr-Abl transplanted recipients in peripheral blood $14 \mathrm{~d}$ after BMT $(n=3 / 3)$. $\mathbf{d}$ Upon autopsy spleen weight of FVB/N wt and FVB/N Bcr-Abl transplanted recipients with the indicated treatment was determined. e Bcr-Abl mRNA expression was analyzed in spleen cells of recipient mice by qRT-PCR. $\mathbf{f}$ FACS analysis of lin $^{-}$cell population of FVB/N wt and FVB/N Bcr-Abl transplanted recipients which received the indicated therapy. $\mathbf{g}$ Distribution of donor (CD45.1) and recipient (CD45.2) derived cells within the LSK (lin $\left.{ }^{-}, \mathrm{c}-\mathrm{kit}^{+}, \mathrm{Sca}-1^{+}\right)$cell compartment of transplanted mice with the indicated treatments. $\left(n=4 / 4 / 3 / 6 / 4,{ }^{*} p<0.05,{ }^{* *} p<0.01,{ }^{* * *} p<0.001\right)$

double treated mice at that time (Fig. 4b). Further analyses of the $\mathrm{PB}$ revealed that donor-derived blasts $\left(\mathrm{CD} 45.1^{+} ; \mathrm{c}-\mathrm{kit}^{+}\right)$were increased in recipients of Bcr-Abl positive $\mathrm{BM}$ and there was a trend of less $\mathrm{CD} 45.1^{+}$; c$\mathrm{kit}^{+}$cells being present in nilotinib re-transplanted mice that was further continued and reduced by 1.88 -fold upon combinatory treatment (Fig. 4c). Donor neutrophils $\left(\mathrm{GrI}^{+}\right.$; $\left.\mathrm{CD} 45.1^{+}\right)$were not increased in the nilotinib re-transplanted animals compared to re-transplanted nilotinib + IFX mice (Fig. 4d). Instead, the donorderived re-expanding cells were positive for the B-cell marker B220 (Fig. 4e) and there was a significant reduction in these cells due to the combinatory treatment as compared to nilotinib monotherapy (11.22-fold). Taken together these data suggest that reduction of FACS positive malignant stem cells seen upon combined treatment in the primary recipients translates into a reduced tendency of these cells to re-expand upon serial transplantation. However, additional experiments would be required to fully address the effect on LSC function.

\section{Discussion}

TKI therapy eliminates the mature leukemic clone in the majority of CML patients but curing the disease by tackling LSC still requires a deeper understanding of the mechanisms allowing for persistence.

A recent report achieved to analyze Bcr-Abl positive vs Bcr-Abl negative stem cells using single-cell RNA sequencing technology. In this article, the authors were able to dissect two distinct LSC subpopulations that are characterized by either a proliferative or a quiescent expression profile [14]. Quiescent LSC expanded during treatment and were associated with inflammatory signatures including TGF $\beta$ und TNF $\alpha$ signaling.
By GSEA analysis we here show that TNFo signaling is the most significant upregulated pathway within the LSK compartment of transgenic CML mice. In these mice TNF $\alpha$ has previously been shown to be elevated in plasma, BM and spleen along with further cytokines including MIP- $1 \alpha$, MIP- $1 \beta$, G-CSF, IL- $1 \alpha$, IL- $1 \alpha$ and IL-6 [32]. Addition of TNF $\alpha$, MIP- $1 \alpha$ and MIP- $1 \beta$ selectively increased CML LT-HSC expansion in vitro in this study. Significant elevation of TNF $\alpha$ in CML patients has likewise been reported upon diagnosis and interestingly this remained at high levels even after 6 months of TKI therapy [9]. Moreover, an autocrine TNFa loop in human CML stem cells has already been shown to persist besides Bcr-Abl kinase inhibition in vitro [33] implying that this could present an attractive stem cell specific target. Indeed, inhibition of TNF $\alpha$ by a small molecule induced apoptosis in CML stem and progenitor cells in vitro [33]. In line with these data, our own data show that addition of TNF $\alpha$ enhanced CFU capacity upon first and serial plating in primary murine CML cells confirming that the cytokine preserves malignant stem cell quality. Additionally, we observed impaired serial plaiting efficiency upon human (IFX) or murine (MP6-XT22) TNF $\alpha$ antibody treatment combined with nilotinib validating that stem cell quality is impaired due to this therapeutic approach. Although we clearly show elevated TNF $\alpha$ expression in Bcr-Abl positive cells, our data also suggest that this is dependent on the malignant kinase, at least in a murine myeloid progenitor cell line. Likewise, we observed reduction of TNF $\alpha$ expression in LSK cells upon long-term reversion of Bcr-Abl expression. However, this could also be due to re-expansion of Bcr-Abl negative LSK cells upon inhibition of the kinase as we have studied the expression

Table 1 Mortality during treatment

\begin{tabular}{lll}
\hline Transplanted cells & Treatment & Day of treatment (spleen size) \\
\hline $1.5 \times 10^{6} \mathrm{Bcr}-\mathrm{Abl} \mathrm{BM}$ & vehicle & day 8 (380 mg), day 12 (n.a.) \\
$1.5 \times 10^{6} \mathrm{Bcr}-\mathrm{Abl} \mathrm{BM}$ & vehicle $+\mathrm{lgG}$ & $\begin{array}{l}\text { day } 9(274 \mathrm{mg}) \text {, day } 12(410 \mathrm{mg}) \text {, } \\
\text { day } 13(77 \mathrm{mg})\end{array}$ \\
$1.5 \times 10^{6} \mathrm{Bcr}-\mathrm{Abl} \mathrm{BM}$ & nilotinib & none \\
$1.5 \times 10^{6} \mathrm{Bcr}-\mathrm{Abl} \mathrm{BM}$ & nilotinib + infliximab & day 7 (91 mg), day $9(108 \mathrm{mg})$ \\
$1.5 \times 10^{6} \mathrm{Wt} \mathrm{BM}$ & vehicle & none \\
\hline
\end{tabular}




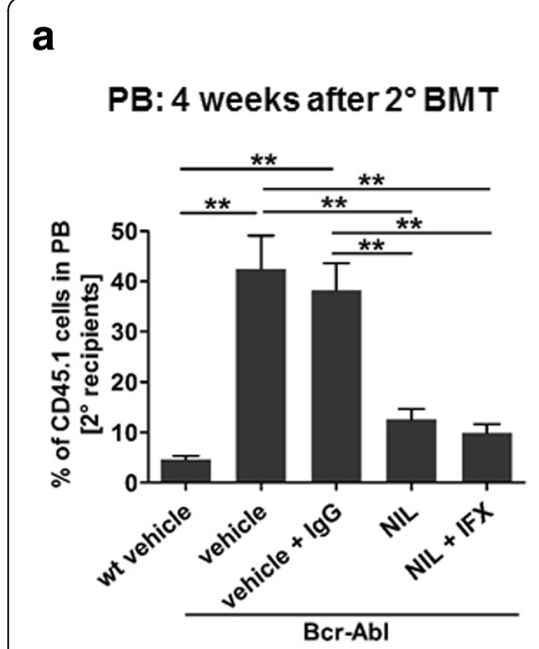

d b

PB: 6 weeks after $2^{\circ} \mathrm{BMT}$

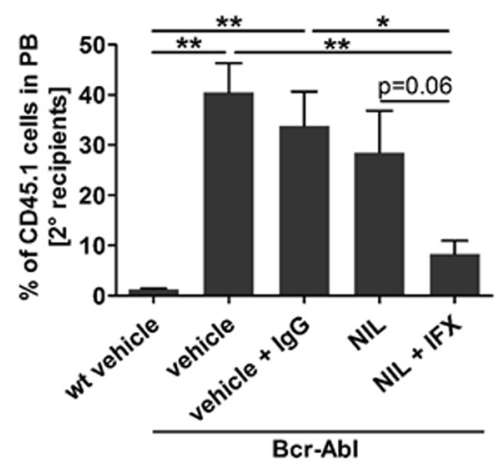

C

PB: 6 weeks after $2^{\circ} \mathrm{BMT}$

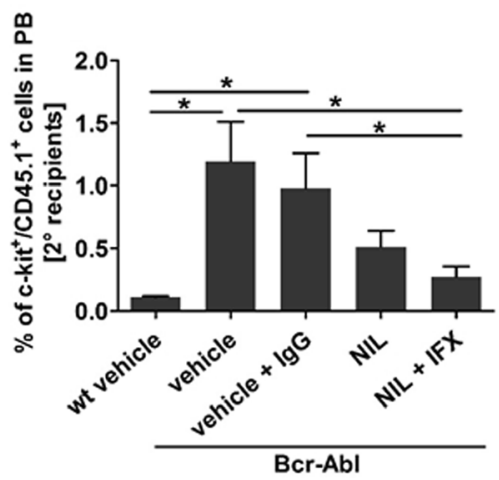

PB: 6 weeks after $2^{\circ} \mathrm{BMT}$

PB: 6 weeks after $2^{\circ} \mathrm{BMT}$
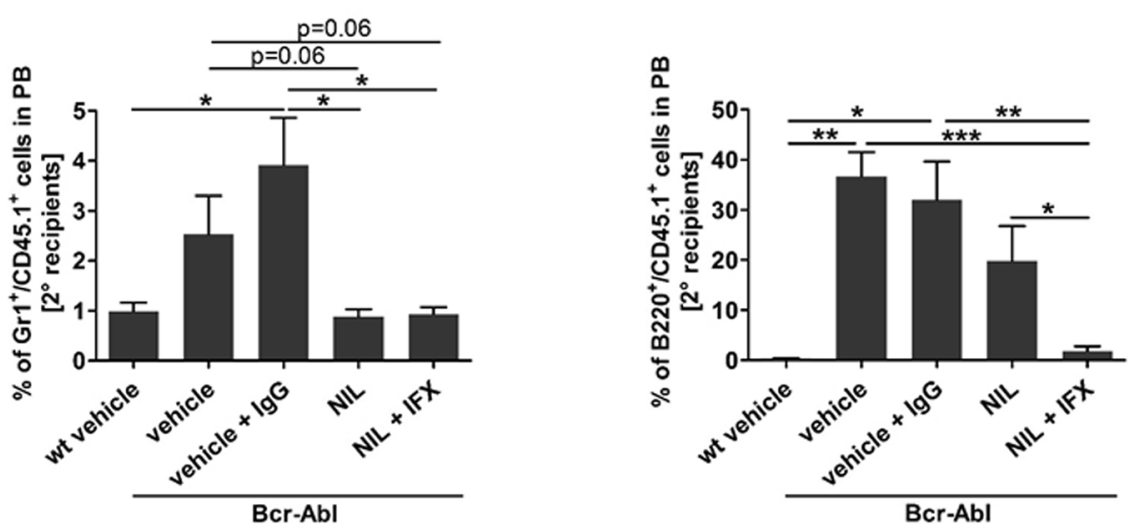

Fig. 4 Serial transplantation reveals impaired malignant stem cell function in mice receiving combination therapy. $3.5 \times 10^{6} \mathrm{CD} 45.1^{+} \mathrm{BM}$ cells from FVB/N wt recipients treated with vehicle and FVB/N Bcr-Abl recipients treated with vehicle, vehicle + IgG, NIL, and NIL+ IFX were transplanted into irradiated secondary CD45.2 FVB/N recipients. a Peripheral blood (PB) from secondary recipients for donor derived CD45.1 ${ }^{+}$cells was assessed by FACS 4 weeks after BMT. 6 weeks after 2nd BMT PB was analyzed by FACS for $\mathbf{b}$ donor derived CD45.1 $1^{+}, \mathbf{c ~} \mathrm{C}^{-k i t^{+}} / \mathrm{CD} 45.1^{+}, \mathbf{d ~ G r}-$ $1^{+} / \mathrm{CD} 45.1^{+}$, and e B220 $/$CD $45.1^{+}$cells. $\left(n=3 / 4 / 4 / 4 / 4,{ }^{*} p<0.05,{ }^{* *} p<0.01,{ }^{* * *} p<0.001\right)$

of TNF $\alpha 48$ days after Bcr-Abl reversion in this model. In primitive human LSCs, TKI persistent TNF $\alpha$ expression has been demonstrated [14, 33]. Yet, additional cell populations could contribute to elevated TNF $\alpha$ levels that are observed in CML mice and patients. This also ties in with the recent finding that CML-derived osteoblasts show elevated levels of TNF $\alpha$ expression, in the SCLtTA/Bcr-Abl model [34].

In another MPN entity an autocrine TNF $\alpha$ function was previously described to support malignant stem cell expansion. Addition of TNF $\alpha$ to human CD34 ${ }^{+}$cells increased cell growth in JAK2V617F positive stem cells [35]. Moreover, TNF $\alpha$ was required for expansion of JAK2V617F cells in a murine transplantation model [36] implying that the LSC promoting TNF $\alpha$ function could be a general phenomenon in MPNs.

Studying the effect of TNF $\alpha$ antibody treatment using our murine primary lin $^{-} \mathrm{CML}$ cells revealed a stronger effect on CFU reduction by IFX as compared to the MP6-XT22 antibody. This observation could be explained by a recent report showing that IFX induces its effects in mice independent of direct TNF $\alpha$ binding [23], although reduction of TNF $\alpha$ upon IFX treatment has been documented in various mouse models [15-20]. The mechanism of IFX induced reduction of murine $\mathrm{TNF} \alpha$ is unclear. It is speculated that the human IgG part of the chimeric antibody might induce apoptosis in TNF $\alpha$ secreting cells. However, at this stage it cannot be 
excluded that IFX-induced effects, independent of TNF $\alpha$, could contribute to the response of CML cells observed in this study. Upon serial transplantation, we observed a non-significant 1.88 -fold reduction in donor-derived ckit $^{+}$cells and a significant 11.22-fold reduction in donorderived $\mathrm{B}_{2} 2 \mathrm{O}^{+}$cells due to combined IFX and nilotinib treatment as compared to nilotinib treatment alone. While the reduction in blasts can be assigned to reduced CML disease the mechanism inducing $\mathrm{B}$-cell reduction is unclear at present but it has been discussed that IFX can alter B-cell biology in treated patients [37, 38] suggesting that this could rather reflect an effect of the antibody treatment itself.

Besides the reduction of TNF $\alpha$ additional inflammatory cytokines such as INF $\gamma$, IL-10 [18] and IL-6 [19] were shown to be reduced in IFX treated mice. We previously demonstrated that the spleen is a reservoir for potent LSC in the SCLtTA/Bcr-Abl mouse model [39] and we analyzed expression of inflammatory cytokines in the spleen of treated mice. While IL-10 and IL-6 were not changed by IFX treatment (data not shown) we found INF $\gamma$ expression to be affected: INF $\gamma$ was downregulated upon CML development and this was partially reverted upon nilotinib treatment while the combination of nilotinib and IFX again antagonized this effect and decreased IFN $\gamma$ expression level (Additional file 3). Intriguingly, IFN $\gamma$ has previously been shown to increase CML CD34 ${ }^{+} \mathrm{CFU}$ numbers [40] and reduce TKIsensitivity of CML cells in vitro [41]. Moreover, therapeutic infusion of cytotoxic T cells (CTL) expanded the LSC compartment in a murine model of late stage CML and this was permitted via IFNY secretion of these CTL [40]. A further report showed that IFNY induces BCL6 expression in CML cells [42] and BCL6 has already been shown to be critical for LSC survival [43]. As combined nilotinib and IFX therapy reduced IFNY expression this could potentially allow for a more potent TKI effect on the LSCs in our model. The mechanism inducing reduced IFN $\gamma$ expression is unclear at present. However, it has been shown that IFX impairs the frequency of IFN $\gamma$ secreting cells. Natural killer cells in rheumatoid arthritis patients were reduced upon IFX therapy [44] and in ulcerative colitis patients derived cells, IFX treatment decreased the proliferation of $\mathrm{CD}^{+}$and $\mathrm{CD} 8^{+} \mathrm{T}$-cells as well as their secretion level of IFN $\gamma$ and TNF $\alpha$, among other cytokines [45]. We have not studied the IFX effect on NK or T-cell populations in the SCLtTA/Bcr-Abl model, yet these data tempt to speculate that IFXmediated activity on NK or T-cell subsets could also be involved in the pathophysiological effects observed in our study.

As a pleiotropic cytokine, TNFa is involved in pro- as well as anti-inflammatory processes and immunosuppressive mechanisms. In this regard, TNF $\alpha$ has been shown to impair conventional T cell survival [46] or promote immunosuppressive cells, such as myeloid-derived suppressor cells (MDSC) $[47,48]$ or regulatory $\mathrm{T}$ cells (Tregs) $[49,50]$. Along this line, IFX therapy in sarcoidosis patients has been shown to reduce elevated frequency of Tregs [51]. Interestingly, CML patients show elevated levels of MDSCs [52, 53] and Tregs [54]. Moreover, CML derived MDSCs themselves have been suggested as a source of TNF $\alpha$ [55], tempting to speculate that TNF $\alpha$ inhibition could also impact on CML biology, not only by direct effects on the malignant stem cell itself but also by supporting a tumor promoting niche.

In several solid cancer entities, TNF $\alpha$ contributes to a pro-carcinogenic microenvironment by activation of NF$\mathrm{KB}$ signaling that promotes cell survival [56, 57]. IFX therapy in mice significantly reduces phosphorylation of RelA (p65) that is a member of the NF- $\mathrm{KB}$ transcription factor family [21]. Inhibition of NF-кB signaling via overexpression of a superrepressor mutant of inhibitory IKB $\alpha$ protein has been shown to impair leukemogenesis in a retroviral model of Bcr-Abl driven disease [58]. In an AML mouse model of Bcr-Abl and NUP98-HoxA9 induced disease autocrine TNFa secretion permitted NF-кB activation in LSC and expanded this disease-initiating cell population [59]. These data tempt to speculate that TNF $\alpha$ could also be involved in advanced CML.

\section{Conclusion}

TNF $\alpha$ signaling is induced in CML stem cells and antiinflammatory therapy elevates TKI induced clonogenic growth reduction. Compatible with this, anti-inflammatory therapy in CML mice enhances TKI induced decline of LSK-cells confirming that successful targeting of CML stem and progenitor cells can be enhanced via addressing their malignant microenvironment simultaneously.

\section{Additional files}

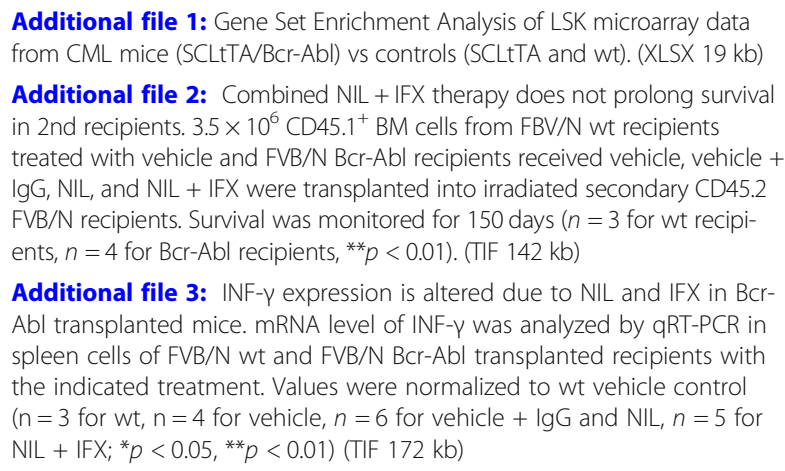

Additional file 3: INF- $\gamma$ expression is altered due to NIL and IFX in BcrAbl transplanted mice. mRNA level of INF- $\gamma$ was analyzed by qRT-PCR in spleen cells of FVB/N wt and FVB/N Bcr-Abl transplanted recipients with the indicated treatment. Values were normalized to wt vehicle control ( $n=3$ for $w t, n=4$ for vehicle, $n=6$ for vehicle $+\operatorname{lgG}$ and $\mathrm{NIL}, n=5$ for $\left.\mathrm{NIL}+\mathrm{IFX} ;{ }^{*} p<0.05,{ }^{* *} p<0.01\right)(\mathrm{TIF} 172 \mathrm{~kb})$

\section{Abbreviations}

BM: Bone marrow; CFU: Colony forming unit; CML: Chronic myeloid leukemia; CP: Chronic phase; IFX: Infliximab; LSC: Leukemic stem cell; 
MPN: Myeloproliferative neoplasm; PB: Peripheral blood; TKl: Tyrosine Kinase Inhibitor; TNF: Tumor necrosis factor; wt: Wildtype

\section{Acknowledgements}

The authors thank Kristina Feldberg and Julia Krings for excellent technical assistance. We thank Hans Häcker for providing the MSCV-ERBDH-Hoxb8-Neo plasmid.

\section{Authors' contribution}

$\mathrm{OH}$, designed research, performed experiments, analyzed the data, and wrote the paper. MKK and MB performed experiments, analyzed the data, and critically revised the manuscript. IGC analyzed the data. IA, FB, TL, TB, SK, THB contributed research material analyzed the data and revised the manuscript. MS designed research, performed experiments, analyzed the data, and wrote the paper. All authors approved the final version of the manuscript.

\section{Funding}

START 691706, DFG 351546. The funding bodies were not involved in either the design of the study, nor in writing the manuscript, or the collection, analysis, or in interpretation of data.

\section{Availability of data and materials}

The dataset analyzed in this study is available under GSE18446; https://www. ncbi.nlm.nih.gov/geo/query/acc.cgi?acc=GSE18446. All additional data generated and analyzed are included in this published article and its supplementary information files.

\section{Ethics approval and consent to participate}

Ethics committee approval was not required for the cell lines applied in this study. Animal experiments were approved by the local authorities (Landesamt für Natur, Umwelt und Verbraucherschutz NRW, LANUV Az. 8402.04.2013. A072).

\section{Consent for publication}

\section{Not applicable}

\section{Competing interests}

The authors declare that they have no competing interest. SK reports having obtained research funding (for different projects) from Novartis and having served on advisory boards for Novartis.

\section{Author details}

'Department of Hematology Oncology Hemostaseology and Stem Cell Transplantation Faculty of Medicine, University Hospital RWTH Aachen, Pauwelsstr 30, 52074 Aachen, Germany. ${ }^{2}$ IZKF Research Group Bioinformatics Institute for Biomedical Engineering, RWTH Aachen University, Aachen, Germany. ${ }^{3}$ Department of Medicine III, University Hospital RWTH Aachen, Aachen, Germany. ${ }^{4}$ Department of Pathology, University Hospital RWTH Aachen, Aachen, Germany.

Received: 26 April 2018 Accepted: 24 June 2019

\section{Published online: 04 July 2019}

\section{References}

1. Eaves C, Udomsakdi C, Cashman J, Barnett M, Eaves A. The biology of normal and neoplastic stem cells in CML. Leuk Lymphoma. 1993;11(Suppl 1):245-53.

2. Bolton-Gillespie $\mathrm{E}$, Schemionek M, Klein HU, Flis S, Hoser G, Lange T, Nieborowska-Skorska M, Maier J, Kerstiens L, Koptyra M, et al. Genomic instability may originate from imatinib-refractory chronic myeloid leukemia stem cells. Blood. 2013;121(20):4175-83.

3. Corbin AS, Agarwal A, Loriaux M, Cortes J, Deininger MW, Druker BJ. Human chronic myeloid leukemia stem cells are insensitive to imatinib despite inhibition of BCR-ABL activity. J Clin Invest. 2011;121(1):396-409.

4. Hamilton A, Helgason GV, Schemionek M, Zhang B, Myssina S, Allan EK, Nicolini FE, Muller-Tidow C, Bhatia R, Brunton VG, et al. Chronic myeloid leukemia stem cells are not dependent on Bcr-Abl kinase activity for their survival. Blood. 2012;119(6):1501-10.

5. Chu S, McDonald T, Lin A, Chakraborty S, Huang Q, Snyder DS, Bhatia R. Persistence of leukemia stem cells in chronic myelogenous leukemia patients in prolonged remission with imatinib treatment. Blood. 2011; 118(20):5565-72.

6. Ross DM, Branford S, Seymour JF, Schwarer AP, Arthur C, Yeung DT, Dang P, Goyne JM, Slader C, Filshie RJ, et al. Safety and efficacy of imatinib cessation for CML patients with stable undetectable minimal residual disease: results from the TWISTER study. Blood. 2013;122(4):515-22.

7. Jiang X, Lopez A, Holyoake T, Eaves A, Eaves C. Autocrine production and action of IL-3 and granulocyte colony-stimulating factor in chronic myeloid leukemia. Proc Natl Acad Sci U S A. 1999;96(22):12804-9.

8. Zhang B, Ho YW, Huang Q, Maeda T, Lin A, Lee SU, Hair A, Holyoake TL, Huettner C, Bhatia R. Altered microenvironmental regulation of leukemic and normal stem cells in chronic myelogenous leukemia. Cancer Cell. 2012; 21(4):577-92.

9. Nievergall E, Reynolds J, Kok CH, Watkins DB, Biondo M, Busfield SJ, Vairo G, Fuller K, Erber WN, Sadras T, et al. TGF-alpha and IL-6 plasma levels selectively identify CML patients who fail to achieve an early molecular response or progress in the first year of therapy. Leukemia. 2016;30(6):1263-72.

10. Reynaud D, Pietras E, Barry-Holson K, Mir A, Binnewies M, Jeanne M, SalaTorra O, Radich JP, Passegue E. IL-6 controls leukemic multipotent progenitor cell fate and contributes to chronic myelogenous leukemia development. Cancer Cell. 2011;20(5):661-73.

11. Welner RS, Amabile G, Bararia D, Czibere A, Yang H, Zhang H, Pontes LL, Ye M, Levantini E, Di Ruscio A, et al. Treatment of chronic myelogenous leukemia by blocking cytokine alterations found in normal stem and progenitor cells. Cancer Cell. 2015;27(5):671-81.

12. Agerstam H, Hansen $N$, von Palffy S, Sanden C, Reckzeh K, Karlsson C, Lilljebjorn H, Landberg N, Askmyr M, Hogberg C, et al. IL1RAP antibodies block IL-1-induced expansion of candidate CML stem cells and mediate cell killing in xenograft models. Blood. 2016;128(23):2683-93.

13. Zhang B, Chu S, Agarwal P, Campbell VL, Hopcroft L, Jorgensen HG, Lin A, Gaal K, Holyoake TL, Bhatia R. Inhibition of interleukin-1 signaling enhances elimination of tyrosine kinase inhibitor-treated CML stem cells. Blood. 2016; 128(23):2671-82.

14. Giustacchini A, Thongjuea S, Barkas N, Woll PS, Povinelli BJ, Booth CAG, Sopp P, Norfo R, Rodriguez-Meira A, Ashley N, et al. Single-cell transcriptomics uncovers distinct molecular signatures of stem cells in chronic myeloid leukemia. Nat Med. 2017;23(6):692-702.

15. Ferrari G, Bignami F, Giacomini C, Franchini S, Rama P. Safety and efficacy of topical infliximab in a mouse model of ocular surface scarring. Invest Ophthalmol Vis Sci. 2013:54(3):1680-8.

16. Deveci F, Muz MH, Ilhan N, Kirkil G, Turgut T, Akpolat N. Evaluation of the anti-inflammatory effect of infliximab in a mouse model of acute asthma. Respirology. 2008;13(4):488-97.

17. Di Paola R, Genovese T, Impellizzeri D, Ahmad A, Cuzzocrea S, Esposito E. The renal injury and inflammation caused by ischemia-reperfusion are reduced by genetic inhibition of TNF-alphaR1: a comparison with infliximab treatment. Eur J Pharmacol. 2013;700(1-3):134-46.

18. Pereira IR, Vilar-Pereira G, Silva AA, Moreira OC, Britto C, Sarmento ED, Lannes-Vieira J. Tumor necrosis factor is a therapeutic target for immunological unbalance and cardiac abnormalities in chronic experimental Chagas' heart disease. Mediat Inflamm. 2014;2014:798078.

19. Yamakawa I, Kojima H, Terashima T, Katagi M, Oi J, Urabe H, Sanada M, Kawai $\mathrm{H}$, Chan L, Yasuda $\mathrm{H}$, et al. Inactivation of TNF-alpha ameliorates diabetic neuropathy in mice. Am J Phys Endocrinol Metab. 2011;301(5):E844-52.

20. Kim YJ, Hong KS, Chung JW, Kim JH, Hahm KB. Prevention of colitis-associated carcinogenesis with infliximab. Cancer Prev Res. 2010;3(10):1314-33.

21. Qiu W, Wu B, Wang X, Buchanan ME, Regueiro MD, Hartman DJ, Schoen RE, Yu J, Zhang L. PUMA-mediated intestinal epithelial apoptosis contributes to ulcerative colitis in humans and mice. J Clin Invest. 2011;121(5):1722-32.

22. Myrelid P, Salim SY, Darby T, Almer S, Melgar S, Andersson P, Soderholm JD. Effects of anti-inflammatory therapy on bursting pressure of colonic anastomosis in murine dextran sulfate sodium induced colitis. Scand J Gastroenterol. 2015;50(8):991-1001.

23. Assas BM, Levison SE, Little M, England H, Battrick L, Bagnall J, McLaughlin $J T$, Paszek P, Else KJ, Pennock JL. Anti-inflammatory effects of infliximab in mice are independent of tumour necrosis factor alpha neutralization. Clin Exp Immunol. 2017;187(2):225-33.

24. Schemionek M, Elling C, Steidl U, Baumer N, Hamilton A, Spieker T, Gothert JR, Stehling M, Wagers A, Huettner CS, et al. BCR-ABL enhances differentiation of long-term repopulating hematopoietic stem cells. Blood. 2010;115(16):3185-95. 
25. Elling C, Erben P, Walz C, Frickenhaus M, Schemionek M, Stehling M, Serve $H$, Cross NC, Hochhaus A, Hofmann WK, et al. Novel imatinib-sensitive PDGFRAactivating point mutations in hypereosinophilic syndrome induce growth factor independence and leukemia-like disease. Blood. 2011;117(10):2935-43.

26. Fahrenkamp D, Herrmann O, Koschmieder S, Brummendorf TH, Schemionek M. Mtss1((CSC156)) mutant mice fail to display efficient Mtss1 protein depletion. Leukemia. 2017;31(4):1017-9.

27. Wang GG, Calvo KR, Pasillas MP, Sykes DB, Hacker H, Kamps MP. Quantitative production of macrophages or neutrophils ex vivo using conditional Hoxb8. Nat Methods. 2006:3(4):287-93.

28. Schemionek M, Herrmann O, Reher MM, Chatain N, Schubert C, Costa IG, Hanzelmann S, Gusmao EG, Kintsler S, Braunschweig T, et al. Mtss1 is a critical epigenetically regulated tumor suppressor in CML. Leukemia. 2016; 30(4):823-32.

29. Han L, Schubert C, Kohler J, Schemionek M, Isfort S, Brummendorf TH, Koschmieder S, Chatain N. Calreticulin-mutant proteins induce megakaryocytic signaling to transform hematopoietic cells and undergo accelerated degradation and Golgi-mediated secretion. J Hematol Oncol. 2016;9(1):45.

30. Schemionek M, Kharabi Masouleh B, Klaile Y, Krug U, Hebestreit K, Schubert C, Dugas M, Buchner T, Wormann B, Hiddemann W, et al. Identification of the adapter molecule MTSS1 as a potential oncogene-specific tumor suppressor in acute myeloid leukemia. PLoS One. 2015;10(5):e0125783.

31. Subramanian A, Tamayo P, Mootha VK, Mukherjee S, Ebert BL, Gillette MA, Paulovich A, Pomeroy SL, Golub TR, Lander ES, et al. Gene set enrichment analysis: a knowledge-based approach for interpreting genome-wide expression profiles. Proc Natl Acad Sci U S A. 2005;102(43):15545-50.

32. Zhang B, Li M, McDonald T, Holyoake TL, Moon RT, Campana D, Shultz L, Bhatia R. Microenvironmental protection of CML stem and progenitor cells from tyrosine kinase inhibitors through $\mathrm{N}$-cadherin and Wnt-beta-catenin signaling. Blood. 2013;121(10):1824-38.

33. Gallipoli P, Pellicano F, Morrison H, Laidlaw K, Allan EK, Bhatia R, Copland M, Jorgensen $\mathrm{HG}$, Holyoake TL. Autocrine TNF-alpha production supports CML stem and progenitor cell survival and enhances their proliferation. Blood. 2013;122(19):3335-9.

34. Schepers K, Pietras EM, Reynaud D, Flach J, Binnewies M, Garg T, Wagers AJ, Hsiao EC, Passegue E. Myeloproliferative neoplasia remodels the endosteal bone marrow niche into a self-reinforcing leukemic niche. Cell Stem Cell. 2013;13(3):285-99.

35. Sollazzo D, Forte D, Polverelli N, Romano M, Perricone M, Rossi L, Ottaviani E, Luatti S, Martinelli G, Vianelli N, et al. Crucial factors of the inflammatory microenvironment (IL-1beta/TNF-alpha/TIMP-1) promote the maintenance of the malignant hemopoietic clone of myelofibrosis: an in vitro study. Oncotarget. 2016;7(28):43974-88.

36. Fleischman AG, Aichberger KJ, Luty SB, Bumm TG, Petersen CL, Doratotaj S, Vasudevan KB, LaTocha DH, Yang F, Press RD, et al. TNFalpha facilitates clonal expansion of JAK2V617F positive cells in myeloproliferative neoplasms. Blood. 2011;118(24):6392-8.

37. Souto-Carneiro MM, Mahadevan V, Takada K, Fritsch-Stork R, Nanki T, Brown M, Fleisher TA, Wilson M, Goldbach-Mansky R, Lipsky PE. Alterations in peripheral blood memory $B$ cells in patients with active rheumatoid arthritis are dependent on the action of tumour necrosis factor. Arthritis Res Ther. 2009;11(3):R84.

38. Timmermans WM, van Laar JA, van der Houwen TB, Kamphuis LS, Bartol SJ, Lam KH, Ouwendijk RJ, Sparrow MP, Gibson PR, van Hagen PM, et al. B-cell dysregulation in Crohn's disease is partially restored with infliximab therapy. PLoS One. 2016;11(7):e0160103.

39. Schemionek M, Spieker T, Kerstiens L, Elling C, Essers M, Trumpp A, Berdel WE, Muller-Tidow C, Koschmieder S. Leukemic spleen cells are more potent than bone marrow-derived cells in a transgenic mouse model of CML. Leukemia. 2012;26(5):1030-7.

40. Schurch C, Riether C, Amrein MA, Ochsenbein AF. Cytotoxic T cells induce proliferation of chronic myeloid leukemia stem cells by secreting interferongamma. J Exp Med. 2013;210(3):605-21.

41. Held SA, Heine A, Kesper AR, Schonberg K, Beckers A, Wolf D, Brossart P. Interferon gamma modulates sensitivity of CML cells to tyrosine kinase inhibitors. Oncoimmunology. 2016;5(1):e1065368.

42. Madapura HS, Nagy N, Ujvari D, Kallas T, Krohnke MCL, Amu S, Bjorkholm M, Stenke L, Mandal PK, McMurray JS, et al. Interferon gamma is a STAT1dependent direct inducer of BCL6 expression in imatinib-treated chronic myeloid leukemia cells. Oncogene. 2017;36(32):4619-28.
43. Hurtz C, Hatzi K, Cerchietti L, Braig M, Park E, Kim YM, Herzog S, RamezaniRad P, Jumaa H, Muller MC, et al. BCL6-mediated repression of p53 is critical for leukemia stem cell survival in chronic myeloid leukemia. J Exp Med. 2011;208(11):2163-74.

44. Coulthard LR, Geiler J, Mathews RJ, Church LD, Dickie LJ, Cooper DL, Wong C, Savic S, Bryer D, Buch MH, et al. Differential effects of infliximab on absolute circulating blood leucocyte counts of innate immune cells in early and late rheumatoid arthritis patients. Clin Exp Immunol. 2012;170(1):36-46.

45. Dahlen R, Strid H, Lundgren A, Isaksson S, Raghavan S, Magnusson MK, Simren M, Sjovall H, Ohman L. Infliximab inhibits activation and effector functions of peripheral blood T cells in vitro from patients with clinically active ulcerative colitis. Scand J Immunol. 2013;78(3):275-84.

46. Ban L, Zhang J, Wang L, Kuhtreiber W, Burger D, Faustman DL. Selective death of autoreactive T cells in human diabetes by TNF or TNF receptor 2 agonism. Proc Natl Acad Sci U S A. 2008;105(36):13644-9.

47. Hu X, Li B, Li X, Zhao X, Wan L, Lin G, Yu M, Wang J, Jiang X, Feng W, et al. Transmembrane TNF-alpha promotes suppressive activities of myeloidderived suppressor cells via TNFR2. J Immunol. 2014;192(3):1320-31.

48. Zhao X, Rong L, Zhao X, Li X, Liu X, Deng J, Wu H, Xu X, Erben U, Wu P, et al. TNF signaling drives myeloid-derived suppressor cell accumulation. J Clin Invest. 2012;122(11):4094-104.

49. Chen X, Baumel M, Mannel DN, Howard OM, Oppenheim JJ. Interaction of TNF with TNF receptor type 2 promotes expansion and function of mouse CD4+CD25+ T regulatory cells. J Immunol. 2007;179(1):154-61.

50. Chen X, Subleski JJ, Kopf H, Howard OM, Mannel DN, Oppenheim JJ. Cutting edge: expression of TNFR2 defines a maximally suppressive subset of mouse CD4+CD25+FoxP3+ T regulatory cells: applicability to tumorinfiltrating T regulatory cells. J Immunol. 2008;180(10):6467-71.

51. Verwoerd A, Hijdra D, Vorselaars AD, Crommelin HA, van Moorsel CH, Grutters JC, Claessen AM. Infliximab therapy balances regulatory T cells, tumour necrosis factor receptor 2 (TNFR2) expression and soluble TNFR2 in sarcoidosis. Clin Exp Immunol. 2016;185(2):263-70.

52. Christiansson L, Soderlund S, Svensson E, Mustjoki S, Bengtsson M, Simonsson B, Olsson-Stromberg U, Loskog AS. Increased level of myeloidderived suppressor cells, programmed death receptor ligand 1/ programmed death receptor 1, and soluble CD25 in Sokal high risk chronic myeloid leukemia. PLoS One. 2013;8(1):e55818.

53. Giallongo C, Parrinello N, Tibullo D, La Cava P, Romano A, Chiarenza A, Barbagallo I, Palumbo GA, Stagno F, Vigneri P, et al. Myeloid derived suppressor cells (MDSCs) are increased and exert immunosuppressive activity together with polymorphonuclear leukocytes (PMNs) in chronic myeloid leukemia patients. PLoS One. 2014;9(7):e101848.

54. Zahran AM, Badrawy $H$, Ibrahim A. Prognostic value of regulatory $T$ cells in newly diagnosed chronic myeloid leukemia patients. Int J Clin Oncol. 2014; 19(4):753-60.

55. Takita M, Tsukahara F, Mishima T, leguchi K, Yamada M, Honda H, Maru Y. Paradoxical counteraction by imatinib against cell death in myeloid progenitor 32D cells expressing p210BCR-ABL. Oncotarget. 2018;9(60):31682-96.

56. Pikarsky E, Porat RM, Stein I, Abramovitch R, Amit S, Kasem S, GutkovichPyest E, Urieli-Shoval S, Galun E, Ben-Neriah Y. NF-kappaB functions as a tumour promoter in inflammation-associated cancer. Nature. 2004; 431(7007):461-6.

57. Greten FR, Eckmann L, Greten TF, Park JM, Li ZW, Egan L, Kagnoff MF, Karin M. IKKbeta links inflammation and tumorigenesis in a mouse model of colitis-associated cancer. Cell. 2004;118(3):285-96.

58. Hsieh MY, Van Etten RA. IKK-dependent activation of NF-kappaB contributes to myeloid and lymphoid leukemogenesis by BCR-ABL1. Blood. 2014; 123(15):2401-11.

59. Kagoya Y, Yoshimi A, Kataoka K, Nakagawa M, Kumano K, Arai S, Kobayashi H, Saito T, Iwakura Y, Kurokawa M. Positive feedback between NF-kappaB and TNF-alpha promotes leukemia-initiating cell capacity. J Clin Invest. 2014; 124(2):528-42

\section{Publisher's Note}

Springer Nature remains neutral with regard to jurisdictional claims in published maps and institutional affiliations. 